$\mathrm{Nr} 2$ (59), 2019, s. 299-325

https://doi.org/10.12797/Politeja.16.2019.59.18

\author{
Magdalena LISIŃSKA (D) \\ Uniwersytet Jagielloński w Krakowie \\ magdalena.lisinska@uj.edu.pl
}

\title{
AMERYKAŃSKA POLITYKA PRAW CZŁOWIEKA WOBEC ARGENTYNY W CZASIE „BRUDNEJ WOJNY” 1976-1983
}

ABSTRACT The U.S. Human Rights Policy towards Argentina during the "Dirty War" of 1976-1983

The paper aims to provide an analysis of the question of violations of human rights during the last military dictatorship in Argentina (1976-1983) and the impact of this problem on bilateral relations with the United States. The article will focus mostly on the presidency of James "Jimmy" Earl Carter. The political line he adopted, known as "the Carter doctrine" or "human rights policy" was the basis of restrictive attitude towards the Argentine dictators. In order to provide a complete analysis, the topic of the paper was treated broadly, covering not only bilateral, American-Argentine issues, but also multilateral forms of exerting pressure on Argentina, mainly from the United Nations and Organization of American States. The article also provides an analysis of the human rights policy itself, as well as of the state terror introduced by the Argentine military, known as the "Dirty War"".

Key words: Argentina, United States, human rights, military dictatorship, "Dirty War"

Słowa kluczowe: Argentyna, Stany Zjednoczone, prawa człowieka, dyktatura wojskowa, „brudna wojna” 


\section{WSTĘP}

Przedmiotem analizy w niniejszym artykule jest kwestia praw człowieka w stosunkach argentyńsko-amerykańskich w czasie tzw. brudnej wojny prowadzonej w Argentynie w okresie dyktatury wojskowej lat 1976-1983. Określenie „brudna wojna” odnosi się do ogółu bezprawnych działań podejmowanych przez rządzących państwem wojskowych, mających na celu zastraszenie społeczeństwa i pokonanie przeciwników politycznych, szczególnie paramilitarnych guerrillas wyznających lewicowe ideologie. Lata 1976-1983 to bez wątpienia jedna z najczarniejszych kart w historii Argentyny. Ofiarą represji ze strony organów państwowych padły w tym okresie tysiące osób, większości z których jedynym przewinieniem było posiadanie odmiennego od elity rządzącej światopoglądu ${ }^{1}$.

W kontekście międzynarodowym represyjna polityka argentyńskiego reżimu nabrała szczególnego znaczenia w relacjach ze Stanami Zjednoczonymi Ameryki, od 1977 roku rządzonymi przez demokratę Jamesa „Jimmy’ego” Earla Cartera. W przeciwieństwie do republikańskiej administracji Geralda Forda, przychylnej przejęciu władzy w Argentynie przez wojsko², stosunek Cartera do argentyńskiego reżimu określić należy jako krytyczny. Polityk ten przykładał szczególną wagę do praw człowieka i związanych z nimi wartości, co znalazło potwierdzenie w polityce zagranicznej prowadzonej przez USA w okresie jego prezydentury. To właśnie przyjęta przez demokratę linia polityczna, określana jako „doktryna Cartera” bądź „polityka praw człowieka”, była podstawą restrykcyjnego i zdecydowanego podejścia USA do nadużyć, jakich dopuszczały się niedemokratyczne reżimy w stosunku do własnych obywateli.

Przedmiotem niniejszego artykułu jest zagadnienie praw człowieka w relacjach argentyńsko-amerykańskich w czasie dyktatury wojskowej w Argentynie w latach 19761983. Celem tekstu jest nie tylko przybliżenie problemu stosunków argentyńsko-amerykańskich w kontekście nadużyć, jakich dopuszczała się junta wojskowa, ale również odpowiedź na pytanie o skuteczność działań prowadzonych przez amerykańską administrację oraz wyciągnięcie wniosków dotyczących całości polityki praw człowieka

Zgodnie z raportem przygotowanym w 1984 r. przez Narodową Komisję do spraw Osób Zaginionych (Comisión Nacional Sobre la Desaparición de Personas, CONADEP), ukazującym skalę łamania praw człowieka w czasie dyktatury, ofiarą represji ze strony reżimu padło 8961 osób. Liczba ta jest jednak znacznie zaniżona, gdyż nie wszystkich udało się zidentyfikować. Obecnie szacuje się, że na skutek pozaprawnych działań podjętych przez aparat państwowy w latach 1976-1983 śmierć ponieść mogło od 15 do nawet 30 tysięcy osób. Por. Nunca más. Informe de la Comisión Nacional sobre la Desaparición de Personas, Buenos Aires 2010; O. Bayer, A.A. Borón, J.C. Gambina, El terrorismo de estado en la Argentina. Apuntes sobre su historia y sus consecuencias, Buenos Aires 2010.

2 Administracja Geralda Forda liczyła, że argentyńscy generałowie poradzą sobie z chaosem panującym w państwie, nie dopuszczając do dalszego wzrostu wpływów grup paramilitarnych powołujących się na lewicowe ideologie. Sprawujący funkcję sekretarza stanu w administracji Forda Henry Kissinger, w obliczu zagrożenia komunizmem w Ameryce Łacińskiej, gotów był ignorować niedemokratyczne i represyjne posunięcia autorytarnych rządów latynoamerykańskich, póki deklarowały one walkę $\mathrm{z}$ wszelkimi przejawami lewicowości. 
Jimmy'ego Cartera. W artykule postawiona została hipoteza, iż amerykańska polityka zagraniczna w stosunku do pogrążonej w „brudnej wojnie” Argentyny nie doprowadziła do pełnej realizacji założeń doktryny praw człowieka, w niewielkim stopniu wpływając na niedemokratyczne praktyki argentyńskiego reżimu wojskowego.

Artykuł przygotowany został w oparciu o metody jakościowe. Podstawowymi narzędziami zastosowanymi w procesie badawczym były analiza i diagnoza, pozwalające na krytyczny przegląd dostępnej literatury, opracowań i dokumentów.

Główna uwaga poświęcona jest w niniejszym tekście działaniom administracji Jimmy'ego Cartera wobec rządzących Argentyną wojskowych. W celu pełnego przedstawienia analizowanego problemu omówiona tematyka potraktowana została jednak w sposób szeroki, obejmujący nie tylko kwestie bilateralne, ale również wielostronne formy nacisku na Argentynę, głównie na forum ONZ i OPA. W przekonaniu autorki artykuł ten nie może abstrahować również od omówienia samej polityki praw człowieka prowadzonej przez Cartera, podobnie jak od przybliżenia specyfiki wprowadzonego przez argentyńskich wojskowych terroru państwowego, którego skutkiem było naruszanie podstawowych wolności na ogromną skalę.

\section{PRAWA CZŁOWIEKA W POLITYCE STANÓW ZJEDNOCZONYCH}

Prawa człowieka oraz związane z nimi wartości obecne były w świadomości Amerykanów już od początku istnienia państwa. Państwowość amerykańska oparta została bowiem na konstytucji, ustanawiającej USA republiką demokratyczną, ale również Karcie Praw Stanów Zjednoczonych ${ }^{3}$, gwarantującej podstawowe wolności i swobody obywatelskie. Pierwszym prezydentem, który w sposób otwarty opowiedział się za koniecznością włączenia wartości do amerykańskiej polityki zagranicznej, był Franklin Delano Roosevelt (1933-1945) ${ }^{4}$, a wątek znaczenia praw człowieka dla amerykańskiego narodu pojawił się w inauguracyjnym przemówieniu prezydenta Johna Fitzgeralda Kennedy'ego w 1961 rokus, jednak upłynąć musiało ponad 200 lat od momentu powstania państwa, aby tematyka ta stała się podstawą i główną osią amerykańskiej doktryny polityki zagranicznej. Prezydent James „Jimmy” Earl Carter, obejmując urząd prezydenta

3 Karta Praw Stanów Zjednoczonych to zbiorcza nazwa dziesięciu pierwszych poprawek do Konstytucji Stanów Zjednoczonych, uchwalonych 25 września 1789 roku. Gwarantowały one podstawowe prawa obywatelskie, takie jak wolność wyznania i prasy, prawo własności prywatnej, prawo zgromadzeń, prawo obrony w procesie karnym, prawo do posiadania i noszenia broni. Poprawki te weszly w życie 15 grudnia 1791 roku.

4 W noworocznym orędziu przedstawionym w 1941 roku proklamował on cztery wolności - słowa, wyznania, wolności od niedostatku i od strachu. Podkreślił on, iż Stany Zjednoczone, jako państwo demokratyczne, musi w pełni solidarnie z innymi demokracjami walczyć o utrzymanie owych wolności, również w obliczu konfliktu światowego. Proklamowane przez Roosevelta wolności, podobnie jak inne podstawowe prawa przysługujące każdej jednostce, zawarte zostały w przyjętej przez Zgromadzenie Ogólne ONZ w 1948 r. Powszechnej Deklaracji Praw Człowieka.

5 John F. Kennedy. Inaugural Address, 20 I 1961, [online] https://www.presidency.ucsb.edu/documents/inaugural-address-2, 3 XI 2019. 
w 1977 roku, ogłosił, że problem praw człowieka i ich przestrzegania na świecie stanowić będzie podstawowy przedmiot zainteresowania amerykańskiej polityki. Wyjątkowość doktryny Cartera przejawiała się również w fakcie, że stanowiła ona najbardziej gruntowną i drastyczną zmianę linii polityki zagranicznej w stosunku do dwóch poprzednich administracji - Richarda Nixona i Geralda Forda ${ }^{6}$.

Należy jednak zwrócić uwagę, że zainteresowanie kwestiami praw człowieka na szczeblu legislatywy widoczne było jeszcze przed dojściem Cartera do władzy. Idee kreowania amerykańskiej polityki zagranicznej w oparciu o zasady moralności zyskały dużą popularność w Kongresie już w połowie lat $70 .^{7} \mathrm{~W}$ przeciwieństwie do sekretarza stanu w administracji Forda, Henry'ego Kissingera, który za niebezpieczne uważał uznawanie problemów wewnętrznych państw za przedmiot zainteresowania amerykańskiej polityki zagranicznej, większość kongresmenów podkreślała znaczenie praw człowieka oraz konieczność ich egzekwowania ${ }^{8}$. W 1974 roku na forum Podkomisji ds. Organizacji i Ruchów Międzynarodowych działającej przy Komisji ds. Spraw Zagranicznych opracowany został raport „Prawa człowieka w społeczności międzynarodowej: wezwanie do przywództwa" (Human Rights in the World Community: A Call for the US Leadership). W jego treści wskazywano konieczność zwiększenia przez Departament Stanu zainteresowania kwestiami praw człowieka w amerykańskiej polityce zagranicznej. Podkreślono, że obecna polityka USA oparta jest na utrzymywaniu ścisłych związków z rządami praktykującymi tortury i gwałcącymi praktycznie wszystkie prawa człowieka. Postawa taka jest moralnie naganna i Stany Zjednoczone powinny jak najszybciej odciąć się od owych partnerów zagranicznych, piętnując ich działania na forum ONZ oraz ograniczając przyznawaną im pomoc finansową i militarną ${ }^{9}$. Kolejnym krokiem podjętym przez Kongres było wprowadzenie w tym samym roku poprawki do ustawy o pomocy zagranicznej z 1961 roku w postaci artykułu 502B. Głosił on, że wszelka pomoc militarna nie może być świadczona partnerom zagranicznym zaangażowanym w poważne naruszenia praw człowieka ${ }^{10}$. Rok później, w 1975 roku, Kongres uchwalił kolejną poprawkę do ustawy z 1961 roku. Poprawka Harkina, której nazwa pochodziła od nazwiska jej pomysłodawcy - demokraty Toma Harkina, zakładała

6 L.P. Bloomfield, From Ideology to Program to Policy. Tracking the Carter Human Rights Policy, „Journal of Policy Analysis and Management" 1982, vol. 2, nr 1, s. 1.

7 Od połowy lat 50. amerykański Kongres zdominowany był przez przedstawicieli Partii Demokratycznej. W latach 70. większość kongresmenów stała więc w opozycji do urzędujących republikańskich prezydentów - Richarda Nixona i Geralda Forda.

8 R. Cohen, Integrating Human Rights in US Foreign Policy. The History, the Challenges, and the Criteria for an Effective Policy, 2008, s. 2, [online] https://www.brookings.edu/wp-content/uploads/2016/06/04_human_rights_cohen.pdf, 3 XI 2019.

9 93rd Congress, 1st session, Human Rights in the World Community: A Call for U.S. Leadership, a Report of the Subcommittee on International Organizations and Movements of the Committee on Foreign Affairs, U.S. Congress, House of Representatives, Washington 1974.

10 Public Law 87-195, Foreign Assistance Act of 1961, Approved September 4, 1961, [online] https:// legcounsel.house.gov/Comps/Foreign\%20Assistance\%20Act\%20Of\%201961.pdf, 10 XI 2018; S.B. Cohen, Conditioning U.S. Security Assistance on Human Rights Practices, „American Journal of International Law" 1982, vol. 76, nr 2, s. 247. 
wprowadzenie do ustawy artykułu 116, zakazującego świadczenia pomocy ekonomicznej państwom gwałcącym prawa człowieka ${ }^{11} .30$ czerwca 1976 roku, jako załącznik do dokumentu z 1961 roku, uchwalona została ustawa o kontroli eksportu broni (Arms Export Control Act), której artykuł 301 w całości dotyczył praw człowieka. Na jego mocy powołany został urząd koordynatora ds. praw człowieka i spraw humanitarnych, działający w obrębie Departamentu Stanu. Jego zadaniem miała być stała obserwacja i gromadzenie informacji dotyczących zagrożenia naruszeń praw człowieka i podstawowych wolności oraz przekazywanie sprawozdań Kongresowi i sekretarzowi stanu ${ }^{12}$.

Należy zwrócić uwagę, że działania Kongresu poprzedzające prezydenturę Cartera, ale również sama linia polityczna obrana przez wybranego w 1976 roku prezydenta, nie stanowiły szeregu przypadkowych decyzji niemających związku z panującą w państwie sytuacją polityczną. Zwrot w kierunku praw człowieka i podkreślanie konieczności włączenia moralności do polityki amerykańskiej były swego rodzaju odpowiedzią na kryzys wartości i wyczerpanie się wzorców dotychczasowego prowadzenia polityki państwa ${ }^{13}$. Porażki armii amerykańskiej w wojnie wietnamskiej zachwiały amerykańskim poczuciem wyjątkowości, budowanym od początku istnienia Stanów Zjednoczonych. Opinia publiczna, przerażona relacjami z toczącej się w odległych Indochinach wojny domowej, zaczęła wątpić w szczerość politycznych deklaracji, określających zaangażowanie amerykańskie w Wietnamie jako walkę o wolność i demokrację ${ }^{14}$. Utrata zaufania do ekipy rządzącej doprowadziła do odsunięcia od władzy demokratów i wyboru w 1969 roku republikanina Richarda Nixona, obiecującego wycofanie się USA z Indochin. Paradoksalnie jednak za sprawą Nixona doszło do jeszcze głębszego kryzysu zaufania. Skandal polityczny, znany jako afera Watergate, ujawnił zaangażowanie administracji prezydenckiej w nielegalne działania skierowane przeciwko przeciwnikom politycznym. W sierpniu 1974 roku prezydent Nixon, w wyniku groźby odsunięcia od władzy w procedurze impeachmentu, zdecydował się zrezygnować z zajmowanego stanowiska ${ }^{15}$. Badania opinii publicznej przeprowadzone w tym okresie wskazywały, iż 71\% Amerykanów uważało, że „sprawy w państwie idą w złym kierunku”, $88 \%$ natomiast utraciło zaufanie do sprawujących władzę w państwie ${ }^{16}$. Kwestią, która w oczach społeczeństwa ostatecznie pogrążyła amerykański aparat państwowy, były ujawnione w połowie lat 70 . nadużycia,

11 C. Apodaca, U.S. Human Rights Policy and Foreign Assistance. A Short History, „Ritsumeikan International Affairs" 2005, vol. 3, s. 67.

12 Public Law 94-329 (The Arms Export Control Act), 30 VI 1974, [online] http://www.gpo.gov/fdsys/ pkg/STATUTE-90/pdf/STATUTE-90-Pg729.pdf, 10 XI 2018.

13 W.M. Schmidli, The Fate of Freedom Elsewhere. Human Rights and U.S. Cold War Policy toward Argentina, Ithaca 2013, s. 1-2.

14 W. Lunch, P.W. Sperlich, American Public Opinion and the War in Vietnam, „The Western Political Quarterly” 1979, vol. 32, nr 1, s. 21-44; R. Cohen, Integrating Human Rights in US Foreign Policy..., s. 2.

15 M. Genovese, I. Morgan, Remembering Watergate, [w:] Watergate Remembered. The Legacy for American Politics, red. M. Genovese, J. Morgan, New York 2012, s. 1-27.

16 T.B. McCrisken, American Exceptionalism and the Legacy of Vietnam. US Foreign Policy since 1974, New York 2003, s. 37. 
których dopuszczały się amerykańskie służby, zarówno CIA, jak i Federalne Biuro Śledcze (Federal Bureau of Investigation, FBI) i Agencja Bezpieczeństwa Krajowego (National Security Agency, NSA). Powołana w Senacie w 1975 roku komisja pod przewodnictwem Franka Churcha opublikowała szereg raportów ujawniających zaangażowanie służb w inwigilację własnych obywateli, ale również próby odsunięcia od władzy zagranicznych przywódców nieprzychylnych Stanom Zjednoczonym. Potwierdzony został udział USA w obaleniu rządów w Iranie w 1953 roku, Gwatemali w 1954 roku oraz Chile w 1973 roku. Ujawniono również liczne próby zamachów na życie Fidela Castro, organizowane przez CIA od czasów rewolucji kubańskiej ${ }^{17}$.

\section{PRAWA CZŁOWIEKA I POLITYKA JIMMY'EGO CARTERA}

Wojna w Wietnamie, afera Watergate oraz ujawnienie nadużyć amerykańskich służb doprowadziły do wzrostu zapotrzebowania społeczeństwa na zmiany, odzyskanie wiarygodności w świecie i odrodzenie amerykańskich wartości. W tym kontekście nie może dziwić błyskotliwy polityczny sukces gubernatora z południowego stanu Georgia - Jimmy'ego Cartera. Już w czasie sprawowania władzy na szczeblu stanowym dał się on poznać jako człowiek bardzo religijny i walczący z segregacją rasową. Podkreślał, że polityczna i społeczna transformacja amerykańskiego Południa stanowi doskonały przykład tego, jak zasady moralne powinny i mogą efektywne wpłynąć na zmiany w strukturze prawnej i społecznej ${ }^{18}$. Odrzucał on tradycyjną dychotomię między idealizmem a realizmem politycznym. Jego zdaniem amerykański idealizm od zawsze był praktycznym i realistycznym podejściem do polityki zagranicznej, a zasady moralne stanowiły najlepszą podstawę do zwiększania amerykańskich wpływów i siły ${ }^{19}$. Paradoksalnie nieco, brak doświadczenia politycznego na szczeblu federalnym oraz niewielka popularność poza rodzimym stanem działały na korzyść demokratycznego kandydata, pozwalając mu sięgnąc po fotel prezydencki w wyborach w 1976 roku. Był on bowiem postrzegany jako człowiek spoza panującego układu politycznego, mogący doprowadzić do odrodzenia amerykańskiej dumy narodowej, zarówno na poziomie krajowym, jak i międzynarodowym. Społeczeństwo wierzyło, że możliwy jest powrót do wartości, na bazie których kształtowana była amerykańska tożsamość narodowa. Nowy prezydent już w czasie kampanii wyborczej podkreślał, że prowadzona do tej pory polityka kłamstw, porażek i korupcji doprowadziła nie tylko do utraty zaufania obywateli do państwa, ale również spadku wiarygodności międzynarodowej Stanów Zjednoczonych $^{20}$. W swoim wygłoszonym 20 stycznia 1977 roku przemówieniu inauguracyjnym

17 D. Schmitz, V. Walker, Jimmy Carter and Foreign Policy of Human Rights. The Development of a PostCold War Foreign Policy, „Diplomatic History” 2004, vol. 28, nr 1, s. 118.

18 J. Carter, Keeping Faith. Memoirs of a President, Toronto 1982, s. 141; D. Schmitz, The United States and Right-Wing Dictatorships, 1965-1989, Cambridge 2006, s. 131.

19 Tamże, s. 143.

20 T.B. McCrisken, American Exceptionalism..., s. 56. 
Carter odwołał się do genezy powstania państwa i wieloletniego przywiązania Amerykanów do wartości, takich jak: moralność, duchowość i wolność. Podkreślił, że zaangażowanie Stanów Zjednoczonych w prawa człowieka musi być absolutne, a Amerykanie, jako ludzie wolni, nigdy nie będą mogli pozostać obojętni na wolność w innych państwach. Mam nadzieję, że $w$ przysztości świat będzie mógt powiedzieć, iż zbudowalismy dtugotrwaty pokój, oparty nie na arsenale wojennym, ale na międzynarodowej polityce odzwierciedlającej nasze najcenniejsze wartości - przekonywał Carter ${ }^{21}$.

Przemówienie inauguracyjne nowego prezydenta stanowi potwierdzenie, że zdaniem Cartera najlepszą drogą do odrodzenia amerykańskiej dumy narodowej miało być uczynienie ze Stanów Zjednoczonych strażnika uniwersalnych i opartych na godności praw wspólnych wszystkim ludziom. Czyniąc odniesienia do wewnątrzamerykańskich uwarunkowań mających być podstawą aktywności państwa na szczeblu międzynarodowym, Carter budował moralne uzasadnienie planowanych działań w polityce międzynarodowej, skupionych na ochronie praw człowieka i podstawowych wartości. Zaletą promowanej przez Cartera polityki był fakt, że koncepcja praw człowieka była uniwersalna i ideologicznie neutralna, a więc odwołująca się do wszystkich jednostek ludzkich, ale jednocześnie mocno ugruntowana w amerykańskiej tradycji. Stawiając prawa człowieka na piedestale, prezydent Carter pragnął zaznaczyć i podkreślić potęgę Stanów Zjednoczonych, opierającą się na czymś więcej niż tylko siła militarna, unikając jednocześnie oskarżeń o imperializm kulturowy i ideologiczny ${ }^{22}$. Podejście takie pozwoliło również na wyznaczenie nowych standardów oceny partnerów zagranicznych Stanów Zjednoczonych, niezależnie od ideologicznych deklaracji. Podmiotem łamiącym prawa człowieka mógł być bowiem zarówno lewicowy dyktator, jak i prawicowy rząd wojskowy. Doktryna Cartera w samym swoim założeniu postulowała więc zastąpienie bipolarnego podziału ideologicznego na podział oparty na moralności i uniwersalnych wartościach, podzielanych przez demokratyczne państwa prawa. Oceniając reżimy pod kątem przestrzegania praw człowieka, Stany Zjednoczone nie musiały więc zdradzać swoich własnych ideałów, popierając antywolnościowe rządy w imię walki ze światowym komunizmem, tak jak się to działo za czasów poprzednich administracji, opierających swoją politykę na pozbawionym moralności realizmie politycznym ${ }^{23}$.

Kwestia przestrzegania praw człowieka poruszona została przez prezydenta Cartera w jego najbardziej znanym przemówieniu dotyczącym polityki zagranicznej, wygłoszonym na Uniwersytecie Notre Dame w stanie Indiana 22 maja 1977 roku. Prezydent skupił się w nim na międzynarodowym zaangażowaniu USA w zakresie ochrony owych praw. Podkreślał, że wszelkie działania podejmowane przez Stany Zjednoczone podyktowane są chęcią zmian na poziomie globalnym, które osiągnąć można tylko poprzez międzynarodową współpracę. Zaznaczył, że konieczne jest pokonanie

\footnotetext{
21 Jimmy Carter: Inaugural Address, 20 I 1977, [online] https://www.presidency.ucsb.edu/documents/ inaugural-address-0, 3 XI 2019, tłum. własne.

22 J. Kane, American Values or Human Rights? U.S. Foreign Policy and the Fractured Myth of Virtuous Power, „Presidential Studies Quarterly” 2003, vol. 33, nr 4, s. 775.

23 Tamże, s. 784-785.
} 
międzynarodowego strachu przed komunizmem, zastępując go wiarą w demokrację i rządy prawa. Wielkie demokracje nie są wolne z powodu swojej poteggi i dostatku. Sa one potężne i dostatnie, gdyż sq wolne - mówił Carter ${ }^{24}$.

Ogłoszona przez Cartera polityka praw człowieka nie mogła ograniczyć się jedynie do deklaracji oraz przemówień. Istotne były również konkretne działania podejmowane przez prezydenta i jego administrację od pierwszych miesięcy urzędowania, mające na celu zarówno wzmocnienie organów odpowiedzialnych za prawa człowieka, jak i wypracowanie jednolitej strategii działania państwa w zakresie przestrzegania owych praw na świecie. Ważną z tego punktu widzenia decyzją było przekształcenie istniejącej od czasów administracji Geralda Forda funkcji koordynatora ds. praw człowieka i spraw humanitarnych. Na mocy decyzji z sierpnia 1977 roku jej ranga została podniesiona do zastępcy sekretarza stanu ds. praw człowieka i spraw humanitarnych. Funkcję tę objęła Patricia M. Derian - znana działaczka w zakresie walki o prawa obywatelskie już od początku lat 60. Dzięki mocnemu zaangażowaniu w organizację kampanii przed wyborami w 1976 roku, udało jej się zdobyć zaufanie również samego Cartera ${ }^{25}$. Dodatkowo, w październiku tego samego roku utworzona została nowa jednostka w ramach Departamentu Stanu, Biuro ds. Praw Człowieka i Spraw Humanitarnych (The Bureau of Human Rights and Humanitarian Affairs).

W kwietniu 1977 roku, z inicjatywy doradcy prezydenta ds. bezpieczeństwa narodowego Zbigniewa Brzezińskiego, powołana została Międzyagencyjna Grupa ds. Praw Człowieka i Pomocy Zagranicznej (Interagency Group on Human Rights and Foreign Assistance), nazywana potocznie Grupą Christophera, od nazwiska swojego przewodniczącego, podsekretarza stanu Warrena Christophera ${ }^{26}$. W skład grupy, poza samym Christopherem, wchodzili przedstawiciele wszystkich departamentów rządowych, Rady Bezpieczeństwa Narodowego, Biura ds. Praw Człowieka i Spraw Humanitarnych oraz Banku Eksportowo-Importowego Stanów Zjednoczonych. Głównym zadaniem grupy miała być analiza wszystkich umów dotyczących pomocy ekonomicznej i militarnej pod kątem przestrzegania praw czlowieka przez ich beneficjentów ${ }^{27} .20$ maja 1977 roku natomiast powołany został Specjalny Komitet Koordynacyjny, którego zadaniem było wypracowywanie rekomendacji w dziedzinie polityki praw człowieka do 1 lipca tego samego roku $^{28}$. Na podstawie raportów z prac dwóch komisji opracowany został pierwszy obszerny dokument administracji Cartera dotyczący praw człowie$\mathrm{ka}$ - robocze memorandum nr 28 (Presidential Review Memorandum/NSC-28: Human Rights). Istotnym elementem owego tajnego dokumentu był przedstawiony w nim podział praw człowieka na trzy podstawowe kategorie. Po pierwsze, była to wolność

24 Jimmy Carter: Address at Commencement Exercises at the University of Notre Dame, 22 V 1977, [online] http://www.presidency.ucsb.edu/ws/index.php?pid=7552, 10 XI 2018, tłum. własne.

25 V.S. Kaufman, The Bureau of Human Rights During the Carter Administration, „The Historian” 1998, vol. 61 , nr 1, s. 52 .

Tamże, s. 53.

27 Tamíe, s. 54.

28 H. Hartmann, US Human Rights Policy under Carter and Reagan, 1977-1981, „Human Rights Quarterly" 2001, vol. 23, nr 2, s. 410. 
od naruszania integralności jednostki przez aparat państwowy, a więc od tortur, nieludzkiego traktowania, kar cielesnych, aresztowania i uwięzienia bez prawomocnego wyroku. Po drugie, prawo do zaspokojenia podstawowych potrzeb człowieka, takich jak: żywność, miejsce zamieszkania, opieka zdrowotna i edukacja. Po trzecie, prawo do posiadania wszelkich swobód obywatelskich i politycznych - wolności wypowiedzi, wyboru religii, prasy, zgromadzeń, brania udziału w życiu politycznym państwa. Autorzy dokumentu zaznaczyli konieczność priorytetowego potraktowania praw pierwszej kategorii, gdyż ich naruszanie uznane zostało przez amerykańską administrację za najpoważniejsze, wymagające bezpośredniej i jak najszybszej interwencji ${ }^{29}$. W dalszej części dokumentu przedstawione zostały ogólne wytyczne w zakresie polityki Stanów Zjednoczonych w dziedzinie praw człowieka oraz cele szczegółowe, dotyczące zarówno zachodnich demokracji, jak i państw komunistycznych, państw trzeciego świata i największych gwałcicieli praw człowieka. W dokumencie tym nie dokonano enumeratywnego wyliczenia państw winnych największych naruszeń praw człowieka, postulując konieczność rzetelnej ich identyfikacji oraz podjęcia stosownych działań w celu wpłynięcia na działania rządów dopuszczających się owych naruszeń ${ }^{30}$.

Rekomendacje wypracowane $\mathrm{w}$ tajnym memorandum stworzyły podstawę dla najważniejszego $\mathrm{z}$ formalnego punktu widzenia dokumentu definiującego politykę USA w zakresie praw człowieka. Zgodnie z wydaną 17 lutego 1978 roku, a więc nieco ponad rok po objęciu przez Cartera urzędu, dyrektywą prezydencką nr 30 (Presidential Directive/NSC-30), głównym celem polityki zagranicznej USA na świecie miało być dbanie o przestrzeganie praw człowieka. W celu promocji przestrzegania owych praw wskazano konieczność zastosowania szerokiego spektrum narzędzi dyplomatycznych, takich jak: publiczne oświadczenia, konsultacje z sojusznikami, współpraca z podmiotami pozarządowymi i organizacjami międzynarodowymi. Podkreślono jednocześnie, że państwa dopuszczające się naruszeń praw człowieka nie będą mogły spodziewać się pomocy ekonomicznej ani militarnej ze strony Stanów Zjednoczonych. Polityka taka realizowana miała być również na forum międzynarodowych instytucji finansowych ${ }^{31}$.

W ciągu pierwszego roku urzędowania administracji Cartera udało się wypracować instytucjonalne oraz prawne podstawy polityki praw człowieka oraz uczynić ją centralnym punktem odniesienia dla amerykańskiej polityki zagranicznej ${ }^{32}$. Znalazło to swoje potwierdzenie w działaniach podejmowanych zarówno na forum organizacji międzynarodowych, jak i bezpośrednio w stosunku do całego szeregu państw oskarżanych przez Amerykanów o naruszenia praw człowieka.

29 D. Schmitz, V. Walker, Jimmy Carter and Foreign Policy..., s. 130.

30 Presidential Review Memorandum/NSC-28: Human Rights, 8 VII 1977, [online] https://fas.org/irp/ offdocs/prm/prm28.pdf, 3 XI 2019.

31 Presidential Directive/NSC-30, 17 II 1978, [online] https://fas.org/irp/offdocs/pd/pd30.pdf, 3 XI 2019.

32 D. Schmitz, V. Walker, Jimmy Carter and Foreign Policy..., s. 136. 


\section{ARGENTYŃSKA „BRUDNA WOJNA”}

Zaprowadzona przez amerykańską administrację polityka praw człowieka znalazła szczególne odniesienie w stosunku do rządzonej przez juntę Argentyny.

Przyczyną, która skłoniła siły zbrojne do przejęcia pełni władzy w Argentynie w 1976 roku, był pogłębiający się chaos państwowy, związany z nieudolnymi rządami peronistów na czele z Maríą Estelą Martínez de Perón (znaną jako Isabel lub Isabelita) oraz aktywnością lewicowych grup paramilitarnych nastawionych na działalność terrorystyczną. Przejmujący władzę wojskowi byli głęboko przekonani, że stanowią oni jedyną grupę posiadającą wszelkie kompetencje pozwalające wyciągnąć państwo z trwającej latami zapaści. Postrzegali się oni jako wyłączni wyraziciele woli narodu, zdolni do trafnej diagnozy i naprawy sytuacji panującej w państwie ${ }^{33}$. Immanentną cechą argentyńskich rządów wojskowych była więc niespotykana dotąd represyjność reżimu, usprawiedliwiana rolą, jaką siły zbrojne przypisywały sobie w państwie. Wojskowi wychodzili bowiem z założenia, że koniecznym jest powstrzymanie wszystkich grup i jednostek odpowiedzialnych za chaos w kraju i siejących zagrożenie dla integralności społecznej, a więc w pierwszej kolejności lewicowych guerrilleros i im przychylnych. Stosowane przez wojskowych represje wynikały również z głębokiego przekonania, że Argentyna znajduje się w stanie wojny totalnej przeciwko światowemu komunizmowi, w której stroną ofensywną, nękającą społeczeństwo argentyńskie, były paramilitarne grupy partyzanckie ${ }^{34}$.Zgodnie ze słowami generała Jorge Rafaela Videli, wojskowi, jako reprezentanci państwa, narodu i tradycji, poczuli się zobligowani do podjęcia walki, której nigdy nie szukali ani nie pożądali. Zostali do niej zmuszeni, akceptując ją jednak ze względu na istniejące zagrożenie dla bytu narodowego ${ }^{35}$. Postrzegali oni walkę z guerrillas jako swego rodzaju zderzenie cywilizacji, a Argentynę jako pierwszy z frontów trzeciej wojny światowej, będącej starciem komunizmu z chrześcijaństwem i wartościami cywilizacji zachodu. Pierwsza wojna światowa byta konfrontacja pomiędzy armiami, druga wojna światowa starciem pomiędzy narodami, trzecia natomiast jest wojna pomiędzy ideologiami - mówił generał Leopoldo Fortunato Galtieri ${ }^{36}$.

Dyskurs argentyńskich wojskowych opierał się na ciągłym podkreślaniu konieczności pokonania wszelkich elementów lewicowych i wywrotowych, zagrażających integralności społecznej. Represyjność reżimu przejawiała się jednak w fakcie, że definicja wywrotowca przedstawiana przez władzę była szeroka, nieostra i obejmować mogła praktycznie każdego obywatela. Zdaniem wojskowych bowiem, za terrorystę mógł być uznany nie tylko ten, kto zabijał z bronią w ręku, ale również każdy, kogo przekonania

33 Proclama, 24 de marzo de 1976, [w:] Documentos básicos y bases politicas de las Fuerzas Armadas para El Proceso de Reorganización Nacional, Buenos Aires 1980.

34 G. Arriagada Herrera, El pensamiento politico de los militares (estudios sobre Chile, Argentina, Brasil y Uruguay), Buenos Aires 1986, s. 177.

35 A.C.G.M. Robben, Political Violence and Trauma in Argentina, Philadelphia 2005, s. 171.

36 A. Graham-Yooll, Buenos Aires, otoño 1982. La guerra de Malvinas según las crónicas de un corresponsal inglés, Buenos Aires 2007, s. 21, tłum. własne. 
były sprzeczne z wartościami wyznawanymi i pielęgnowanymi przez sprawujących władzę w państwie ${ }^{37}$. Każdy, kto nie zgadza się $z$ naszym sposobem życia i krytykuje rząd wojskowy, poniesie konsekwencje - mówił generał Jorge Rafael Videla ${ }^{38}$. Nie ulega wątpliwości, że tego typu sformułowania były dla wojskowych pretekstem do stosowania przemocy w stosunku do każdej praktycznie jednostki. Warto również podkreślić, że sprawujący władzę generałowie postrzegali podejmowane przez nich działania jedynie w kontekście obrony własnej, odcinając się od zarzutów stosowania przemocy w stosunku do własnych obywateli. Wywrotowcy, z którymi walczono, zostali bowiem przez wojskowych niejako wykluczeni z narodu argentyńskiego, a ich eliminacja często porównywana była do konieczności pozbycia się choroby z organizmu ${ }^{39}$.

Wypracowana przez juntę wojskową metodologia działań oparta była z jednej strony na konieczności szybkiej walki z przeciwnikami, z drugiej natomiast - na chęci zapobieżenia wykształceniu się frontu poparcia społecznego dla wywrotowców, poprzez wzbudzenie wśród ludzi stałego poczucia strachu i zagrożenia. Taką właśnie formą represji były wymuszone zaginięcia (desapariciónes) - stosowane przez juntę na masową skalę porwania osób podejrzanych o sympatie opozycyjne przez działające incognito służby państwowe. $Z$ punktu widzenia sił zbrojnych metoda ta wydawała się wyjątkowo racjonalna, pozwalała bowiem na efektywną eliminację jednostek niepożądanych, a dzięki działaniu poza nawiasem obowiązującego prawa dawała wojskowym swobodę doboru narzędzi, jednocześnie zwalniając ich od wszelkiego rodzaju kontroli i odpowiedzialności ${ }^{40}$. Sposób działania aparatu państwowego w stosunku do osób podejrzanych o sympatie prokomunistyczne oparty był na dokładnym planie, podzielonym na cztery podstawowe części: porwanie, tortury, przetrzymywanie i egzekucjęㄹ. W pierwszym etapie grupa operacyjna funkcjonariuszy wojskowych ubranych w cywilne stroje, określana jako la patota, dokonywała porwania podejrzanego. Działania te podejmowano najczęściej w nocy, wyprowadzając jednostkę z domu na oczach rodziny, zdarzały się jednak również przypadki porwań $\mathrm{w}$ biały dzień - z miejsc pracy bądź z ulicy. Podejrzani przewożeni byli do tajnych centrów wojskowych, gdzie poddawano ich wymyślnym torturom, mającym na celu uzyskanie informacji pomocnych $w$ dalszych aresztowaniach. Centra te pełniły jednocześnie funkcję więzień, w których przetrzymywani byli osadzeni. Najbardziej znanym centrum przetrzymywania więźniów politycznych

Argentina since Independence, red. L. Bethell, Cambridge 1993, s. 328.

38 Wypowiedź generała Jorge Videli przytoczona w artykule Why Argentina Declared War on 'Guerrillas of the Mind', „The London Times” 1977, 20 IV, s. 16; cyt. za: K. Hollingshead-Cook, Ideology vs. Practice in Argentina's Dirty War Repression, University of Tennessee Honors Thesis Projects, s. 12, [online] http://trace.tennessee.edu/cgi/viewcontent.cgi ?article=1969\&context=utk_chanhonoproj, 25 VI 2015, tłum. własne.

39 N. Bravo, El discurso de la dictadura militar argentina (1976-1983). Definición del opositor politico y confinamiento - „valorización” del papel de la mujer en el espacio privado, „Utopía y Praxis Latinoamericana" 2003, nr 22, s. 112.

40 A.C. Armony, Argentina, the United States, and the Anti-Communist Crusade in Central America, 1977-1984, Athens, OH 1997, s. 6.

41 L.A. Romero, Breve historia contemporánea de la Argentina, Buenos Aires 2001, s. 208. 
w okresie dyktatury była Szkoła Mechaników Marynarki Wojennej (Escuela de Mecánica de la Armada, ESMA), przez którą w latach 1976-1979 przewinęło się około 300-500 osadzonych. Zdecydowana większość więźniów nie przeżywała tortur bądź umierała $\mathrm{w}$ drodze przeprowadzanych egzekucji. Powszechną praktyką stosowaną przez argentyńską juntę były tzw. loty śmierci - zrzucanie więźniów politycznych z samolotu do Atlantyku. Zgodnie z szacunkami jednego z wojskowych biorących w nich udział, w dwa lata zabito tą metodą od 1500 do 2000 osób ${ }^{42}$.

Jak wcześniej zostało podkreślone, celem represji nie było wyłącznie wyeliminowanie podejrzanych o działalność wywrotową, ale również zastraszenie społeczeństwa jako całości. W czasie rządów junty wojskowej wykształciła się w Argentynie swego rodzaju „kultura strachu”. Nikt nie mógł być pewny swojej niewinności, co potwierdzać mogą słowa jednego $\mathrm{z}$ argentyńskich generałów, sprawującego funkcję gubernatora prowincji Buenos Aires, Ibérica Saint-Jean'a: Najpierw zabijemy wszystkich wywrotowców, później tych, którzy im pomagali, następnie tych, którzy z nimi sympatyzowali i tych, którzy pozostali obojętni. Na końcu zaś zabijemy bojaźliwych ${ }^{43}$.

\section{ADMINISTRACJA CARTERA A ARGENTYŃSKA „BRUDNA WOJNA”}

W przeciwieństwie do administracji Forda, antydemokratyczne i niehumanitarne praktyki stosowane przez rząd wojskowy zwróciły uwagę Cartera i jego urzędników, których działania w stosunku do Argentyny całkowicie zmienić miały poprawne dotąd stosunki na linii Waszyngton - Buenos Aires. Już od pierwszych tygodni rządów Cartera amerykańscy urzędnicy otrzymywali liczne informacje o naruszeniach praw człowieka w Argentynie, łącznie z prośbami o pomoc ze strony rodzin zaginionych ofiar dyktatury. Jeszcze przed oficjalną nominacją na funkcję zastępcy sekretarza stanu, po raz pierwszy do Buenos Aires udała się Patricia M. Derian. Celem wizyty miała być ocena stanu przestrzegania praw człowieka w państwie. Rozmawiając z przedstawicielami argentyńskich organizacji pozarządowych, pracownikami ambasady amerykańskiej i argentyńskimi urzędnikami państwowymi, przekonała się ona, jak bardzo istotne miejsce w ówczesnym dyskursie publicznym zajmowała kwestia wojny z wpływami komunistycznymi i wywrotowcami. Niepokojące wrażenia, jakie wywarła na Derian wizyta w Buenos Aires, sprawiły, że stała się ona wielką przeciwniczką dalszego udzielania pomocy finansowej Argentynie ${ }^{44}$.

Krytyka Stanów Zjednoczonych pod adresem Argentyny była dla rządzącej junty całkowicie niezrozumiała. $Z$ ich punktu widzenia USA, podobnie jak inne państwa zachodnie, nie zdawały sobie sprawy ze skali ofensywy komunizmu sowieckiego, który

42 H. Verbitsky, Confessions of an Argentine Dirty Warrior, New York 2005, s. 51.

43 Wypowiedź generała Ibérica Saint-Jean'a przytoczona w artykule Avoiding the Worst in Argentina, „The New York Times”, 1977, 25 V, s. 26; cyt. za: K. Hollingshead-Cook, Ideology vs. Practice..., s. 12, tłum. własne.

44 W.M. Schmidli, Institutionalizing Human Rights in U.S. Foreign Policy. U.S.-Argentine Relations, 1976-1980, „Diplomatic History” 2001, vol. 35, nr 2, s. 353. 
z powodzeniem zdobywał kolejne fronty na kontynentach amerykańskich. W przeciwieństwie do obojętnego Zachodu, Argentyna była w oczach wojskowych państwem niebojącym się stawić czoła zagrożeniu, biorącym odpowiedzialność za losy nie tylko regionu, ale całego świata. Trudno było im przejść do porządku dziennego nad faktem, że nowa administracja amerykańska kwestionowała przyjęte przez nich metody walki z wywrotowcami destabilizującymi państwo. Argentyńscy wojskowi byli absolutnie przekonani o słuszności podejmowanych działań, starając się przekonać społeczność międzynarodową, że prowadzona przez nich „brudna wojna” stanowi zbrojną odpowiedź na zagrożenie światowym komunizmem. Jednocześnie zaś całkowicie zaprzeczali oni istnieniu w Argentynie problemu wymuszonych zaginięć, wszelkie wpływające skargi w tym zakresie określając jako umotywowane politycznie i nieprawdziwe. Oficjalna instrukcja dotycząca konieczności zaprzeczania wiarygodności doniesień dotyczących naruszeń praw człowieka w Argentynie wydana została na początku 1977 roku przez argentyńskie Ministerstwo Spraw Zagranicznych i rozesłana do wszystkich urzędujących ambasadorów ${ }^{45}$.

Niezmiennie wysoka represyjność argentyńskiego reżimu i powiększająca się liczba osób zaginionych stały się przyczynkiem do coraz śmielszych prób umiędzynarodowienia przez rodziny ofiar panującej w Argentynie sytuacji. Symbolem oporu wobec władz stały się Matki z Placu Majowego (Madres de Plaza de Mayo) - nieformalna organizacja kobiet domagających się prawdy o swoich zaginionych dzieciach. W celu nagłośnienia problemu Matki wysyłały swoje przedstawicielki na spotkania z urzędnikami państw zachodnich, pisały petycje, wystawiały ogłoszenia w prasie zagranicznej. Bardzo pomocna okazała się ambasada USA w Buenos Aires, szczególnie zaś jej sekretarz, Tex Harris, który przekazywał Matkom informacje o terminach wizyt amerykańskich urzędników oraz pomagał w nawiązaniu międzynarodowych kontaktów. Dzięki Harrisowi amerykańska ambasada stała się swego rodzaju „centrum pomocy” w dziedzinie praw człowieka, gdzie każdy poszkodowany mógł złożyć doniesienie w sprawie nadużyć ze strony władz. W ciągu kilku miesięcy zgłosiły się dziesiątki osób, aczkolwiek sam Harris miał świadomość, że jest to jedynie wierzchołek góry lodowej. Współpracując z Matkami oraz innymi argentyńskimi organizacjami pozarządowymi, opracowywał on regularne raporty o stanie przestrzegania praw człowieka w Argentynie, przesyłając je następnie do Biura ds. Praw Człowieka i Spraw Humanitarnych ${ }^{46}$.

Zaostrzające się stanowisko Stanów Zjednoczonych, znajdujące swoje potwierdzenie w decyzji o zmniejszeniu pomocy militarnej wysyłanej do Buenos Aires, wymusiło na argentyńskich wojskowych złagodzenie podejścia do wysuwanych pod ich adresem oskarżeń. W czasie drugiej wizyty Patricii Derian w Argentynie, w sierpniu 1977 roku, widoczna była zmiana w stanowisku prezydenta Jorge Videli, wcześniej tak przeciwnego poruszaniu kwestii praw człowieka. Przyznał on, że istotnie, w Argentynie dochodzi do przypadków zaginięć, jednak zdecydowana większość z nich związana jest

45 M. Novaro, V. Palermo, La dictadura militar, 1976/1983. Del golpe de estado a la restauración democrática, Buenos Aires 2011, s. 280, Historia Argentina, 9.

46

W.M. Schmidli, Institutionalizing Human Rights..., s. 40. 
z działalnością lewicowych partyzantek. Przekonywał, że jedynie niewielka ich część, określona jako „incydenty”, mogła być wynikiem działań służb państwowych. Obiecał jednocześnie unikanie tego typu wypadków w przyszłości ${ }^{47}$. Videla przyjął podobne stanowisko również w czasie wizyty w Stanach Zjednoczonych, w związku z podpisaniem układów panamskich Torrijos - Carter ${ }^{48}$ we wrześniu 1977 roku. W owym czasie problem niskich standardów przestrzegania praw człowieka w Argentynie stał się dodatkowo głośny za sprawą porwania Alfreda Bravo, jednego z liderów Stałego Zgromadzenia Praw Człowieka (Asamblea Permanente por los Derechos Humanos, APDH) - największej i najaktywniejszej argentyńskiej organizacji powstałej jeszcze przed dyktaturą wojskową jako reakcji na rosnącą falę przemocy w państwie. W trakcie konferencji prasowej przeprowadzonej po spotkaniu z Videlą prezydent Carter zwrócił uwagę na konieczność szybkiego uregulowania przez Argentynę kwestii osób więzionych - postawienia ich przed sądem oraz poinformowania społeczności międzynarodowej o statusie owych jednostek ${ }^{49}$. W odpowiedzi na rosnące zainteresowanie mediów i przedstawicieli zagranicznych sprawą wymuszonych zaginięć prezydent Videla stwierdził, że prowadzona jest niedopuszczalna „antyargentyńska nagonka”. Określił on organizacje oskarżające jego rząd o systematyczne i rażące nadużycia jako „przesiąknięte marksistowskim elementem wywrotowym" ${ }^{50}$. Aby uspokoić nastroje i uciszyć międzynarodowe protesty, argentyński rząd zdecydował się jednak ująć sprawę Alfreda Bravo w ramy prawne, a sam zainteresowany postawiony został przed wymiarem sprawiedliwości. Niedługo później, również w wyniku nacisków społeczności międzynarodowej, doszło do uwolnienia $\mathrm{z}$ więzienia przedstawicieli innej organizacji walczącej o prawa człowieka - Centrum Badań Prawnych i Społecznych (Centro de Estudios Legales y Sociales, CELS) $)^{51}$.

Już pod koniec 1977 roku dla prezydenta Cartera i jego administracji stało się jasne, że pojedyncze, pokazowe gesty ze strony generałów nie stanowią przekonującego dowodu liberalizacji argentyńskiego reżimu. W listopadzie tego roku z wizytą do Buenos Aires udał się więc amerykański sekretarz stanu, Cyrus Vance. W czasie spotkania z prezydentem Videlą przedstawił on listę 7500 osób, których zaginięcie zgłoszono do amerykańskiej ambasady, naciskając, aby junta wojskowa upubliczniła wszystkie

47 Derian Call on President Videla, 11 VIII 1977, [online] https://aad.archives.gov/aad/createpdf?rid $=181457 \& \mathrm{dt}=2532 \& \mathrm{dl}=1629,3$ XI 2019.

48 Zawarty w 1977 roku układ między prezydentami Panamy - Omarem Torrijosem i Stanów Zjednoczonych - Jimmym Carterem regulował kwestię zwierzchności strefy Kanału Panamskiego. Na jego mocy nastąpić miało stopniowe przekazywanie zarządzania strefą Panamie, aż do pełnej zwierzchności w 1999 roku. Na uroczystość podpisania układów zaproszeni zostali przywódcy państw latynoamerykańskich, w tym generał Videla.

49 Meeting with President Jorge Rafael Videla of Argentina Remarks to Reporters Following the Meeting, 9 IX 1977, [w:] Weekly Compilation of Presidential Documents, Monday, July 4, 1977, vol. 13, nr 27, s. 1309-1310.

50 M. Novaro, V. Palermo, La dictadura militar..., s. 281.

51 A. Brysk, The Politics of Human Rights in Argentina. Protest, Change, and Democratization, Stanford 1994, s. 55. 
nazwiska zaginionych ${ }^{52}$. Argentyńscy wojskowi nie mogli się na to zgodzić. Wizyta Vance'a w Buenos Aires, szczególnie zaś głośna odmowa upublicznienia listy zaginionych przez juntę, tylko pogorszyła opinię amerykańskich decydentów o Argentynie. Było już pewne, że po zmniejszeniu pomocy militarnej przyznawanej Argentynie następnym krokiem podjętym przez Stany Zjednoczone będzie całkowite odcięcie Buenos Aires od amerykańskich środków na cele wojskowe. Na początku 1978 roku argentyński minister ekonomii José Alfredo Martínez de Hoz dowiedział się również, że z inspiracji Stanów Zjednoczonych argentyńskie starania o kredyty w Banku Światowym i Międzyamerykańskim Banku Rozwoju nie będą rozpatrywane do momentu zmniejszenia represyjności reżimu ${ }^{53}$. Na przełomie 1977 i 1978 roku prezydent Videla odbył wizyty międzynarodowe w Paragwaju, Brazylii, Urugwaju i Peru, by uformować front poparcia dla Argentyny pod hasłem ochrony prawa do samostanowienia i sprzeciwu wobec ingerencji Stanów Zjednoczonych w działania państw latynoamerykańskich. Wojskowym udało się uzyskać solidarność regionalną, nie przełożyła się ona jednak na konkretne działania dyplomatyczne, mogące zminimalizować lub zrekompensować nakładane przez Stany Zjednoczone sankcje ${ }^{54}$.

Należy zwrócić uwagę, że naciski Stanów Zjednoczonych na Argentynę w zakresie praw człowieka wykraczały poza relacje bilateralne, odbijając się szerokim echem w organizacjach międzynarodowych, szczególnie zaś na forum ONZ i OPA. W przypadku obydwu organizacji działania przeciwko Argentynie podejmowane były dwutorowo: na forum zgromadzenia plenarnego oraz $w$ wyspecjalizowanych komisjach zajmujących się prawami człowieka.

Dzięki zaangażowaniu rządu amerykańskiego, jak również argentyńskich i międzynarodowych organizacji walczących o prawa człowieka, problem Argentyny przedstawiony został Zgromadzeniu Ogólnemu ONZ w 1978 roku. W tym samym roku przyjęta została rezolucja 33/173, dotycząca wymuszonych zaginięć. W treści dokumentu określono ową praktykę jako poważne naruszenie praw człowieka, wzywając społeczność międzynarodową do działań mających na celu jej zapobieżenie ${ }^{55}$. Rezolucja ta, mimo że nie wymieniała winnych tego typu nadużyć, stanowiła oficjalną podstawę do międzynarodowego potępienia państw, w których wymuszone zaginięcia były metodą represjonowania społeczeństwa, a więc również Argentyny.

Pierwsze doniesienia o represyjności reżimu argentyńskiego, szczególnie zaś coraz częstszych zniknięciach opozycji politycznej, dotarły na forum Komisji Praw Człowieka ONZ już pod koniec 1976 roku. Obserwując poważne skutki handlowe i finansowe, jakie niosły za sobą potępienie apartheidu w RPA oraz rządów generała Pinocheta w Chile, argentyński ambasador w Genewie, Gabriel Martínez, za wszelka cenę dążyt do

52 R. Cohen, Human Rights Diplomacy. The Carter Administration and the Southern Cone, „Human Rights Quarterly" 1982, vol. 4, nr 2, s. 218.

53 M. Novaro, V. Palermo, La dictadura militar..., s. 282.

54 Tamże.

55 United Nations, Resolution 33/173, Disappeared persons, 20 XII 1978, [online] https://undocs.org/ pdf ?symbol=en/A/RES/33/173, 3 XI 2019. 
zmniejszenia zainteresowania komisji kwestia Argentyny. Dzięki poparciu ze strony części państw bloku socjalistycznego oraz państw niezaangażowanych, stanowczo sprzeciwiajacych się ingerencji USA w politykę wewnętrzna państw trzecich, w 1977 roku Argentyna znalazta siępoza lista państw „systematycznie tamiacych prawa cztowieka”. Zwiazek Radziecki, jeden z najważniejszych partnerów handlowych Argentyny, przyczynit sięrównież do zablokowania prób potępienia rządu wojskowego na forum organizacji, do których dochodzito w roku 1978. Argentyna i jej sojusznicy przeciwni byli również powotaniu specjalnej Grupy Roboczej ds. Wymuszonych Zaginięć. Projekt powotania grupy przegtosowano dopiero 1980 roku, grożąc Argentynie, że w razie dalszego jego blokowania wystosowana zostanie rezolucja potępiająca wymuszone zaginięcia, whtórej wymienione będą dwa państwa: Argentyna i Chile. Kiedy stato się jasne, że rezolucja cieszy się poparciem większości obecnych na sesji plenarnej $w$ Genewie, $w$ zamian za rezygnacje z poddawania projektu pod gtosowanie, delegacja argentyńska zgodzita się na powotanie grupy roboczej $j^{56}$.

Temat praw człowieka poruszony został również w trakcie siódmego Zgromadzenia Ogólnego OPA w Grenadzie w 1977 roku. W czasie obrad argentyńska delegacja jednoznacznie odmówiła wyrażenia zgody na wizytę w państwie przedstawicieli Międzyamerykańskiej Komisji Praw Człowieka (Comisión Interamericana de Derechos Humanos, CIDH) - organu OPA, którego zadaniem było kontrolowanie rządów z punktu widzenia przestrzegania praw człowieka oraz sporządzanie odpowiednich raportów. Celem argentyńskiej dyplomacji było dobitne pokazanie społeczności międzynarodowej, kto jej zdaniem odpowiedzialny jest za nadużycia i przemoc, o które oskarżany jest rząd wojskowy. Przedstawiciel delegacji Argentyny, Juan Carlos Arliz, przedstawił projekt rezolucji, w której skrytykowano promowaną przez administrację Cartera koncepcję, jakoby głównymi odpowiedzialnymi za naruszenia praw człowieka były rządy państw. Zdaniem Arliza, OPA powinna zająć się zbrodniami popełnianymi przez jednostki oraz grupy terrorystyczne, współpracując jednocześnie z rządami $\mathrm{z}$ terroryzmem walczącymi ${ }^{57}$. Obecny na posiedzeniu minister spraw zagranicznych Argentyny, wiceadmirał Oscar Antonio Montes, zaproponowal, aby CIDH rozszerzyła swoje kompetencje na badanie przypadków naruszeń dokonywanych przez grupy wywrotowe. Na poparcie swojej propozycji przywołał próby zamachów na życie jego poprzednika - ministra Césara Augusta Guzzettiego oraz szefa dyplomacji Salvadoru, Mauricia Borgonovy, których organizatorami byli członkowie lewicowych bojówek terrorystycznych ${ }^{58}$. Propozycja wysunięta przez Argentynę była absolutnie nie do przyjęcia przez Stany Zjednoczone, co poskutkowało przedstawieniem projektu rezolucji podkreślającej, że żadne okoliczności nie mogą usprawiedliwiać tortur, pozbawiania życia i więzienia bez sądu, wbrew obowiązującemu prawu. Mimo usilnych starań delegacji argentyńskiej, owa „dyplomatyczna potyczka” zakończyła się zwycięstwem USA,

56 P.J. Flood, The Effectiveness of U.N. Human Rights Institutions, Westport, CT 1998, s. 55.

57 A. Cisneros, C. Escudé, Las relaciones con Estados Unidos, [w:] Historia general de las relaciones exteriores de la República Argentina, t. 14: Las relaciones politicas, 1966-1989, [online] http://www.argentina-rree.com/14/14-043.htm, 12 XI 2018.

58

Tamże. 
których rezolucja poparta została przez 14 państw, przy ośmiu głosach wstrzymujących się (Argentyny, Brazylii, Chile, Gwatemali, Kolumbii, Paragwaju, Salwadoru i Urugwaju) i braku głosów przeciw. Za propozycją argentyńską opowiedziało się 11 państw, cztery wstrzymały się od głosu, a sześć było przeciwnych (Grenada, Jamajka, Panama, Stany Zjednoczone, Trinidad i Tobago oraz Wenezuela ${ }^{59}$.

Naciskom ze strony organizacji międzynarodowych towarzyszyły coraz poważniejsze sankcje nakładane przez Stany Zjednoczone, których apogeum przypadło na rok 1978. Wtedy właśnie w życie weszła tzw. Poprawka Humphreya-Kennedy’ego, blokująca wszelką pomoc militarną udzielaną Argentynie. Poza ograniczeniami na wydatki wojskowe, w okresie do sierpnia 1978 roku USA zawiesiły przyznawane dotychczas Argentynie pożyczki na łączną kwotę około 1,25 mld dolarów, w tym 11 kredytów Banku Eksportowo-Importowego Stanów Zjednoczonych o wartości $600 \mathrm{mln}$ dolarów $^{60}$. Argentyńscy wojskowi zdali sobie sprawę, że podejmowane przez nich wysiłki mające na celu przekonanie świata, iż ich państwo stało się ofiarą nagonki ze strony USA, nie dają większego efektu. Już na początku 1978 roku, w obliczu zbliżających się mistrzostw świata w piłce nożnej, zdecydowali się oni na skorzystanie z usług prywatnych firm amerykańskich zajmujących się public relations, w celu poprawy wizerunku państwa. Do przyjazdu do Argentyny zachęcać miały malownicze krajobrazy przedstawiane w kolorze w amerykańskiej prasie ${ }^{61}$. Trzeba podkreślić, że sam rozgrywany w Argentynie mundial był swego rodzaju próbą odciągnięcia uwagi świata od niedemokratycznych realiów życia w państwie. Zdaniem niektórych komentatorów, motywy organizacji tak dużej imprezy międzynarodowej przez Argentynę były tożsame z tymi kierującymi hitlerowskimi Niemcami przy organizacji igrzysk olimpijskich w roku $1936^{62}$.

Warto zwrócić uwagę, że nagłośnienie problemu niskich standardów przestrzegania praw człowieka w Argentynie nie tylko pogorszyło międzynarodowy wizerunek państwa, ale również stało się pretekstem do rozgrywek politycznych i walk o władzę wewnątrz armii. Aspiracje zwiększenia wpływów widoczne były szczególnie w marynarce wojennej, na czele której do końca 1978 roku stał Emilio Eduardo Massera, członek pierwszej junty wojskowej. Admirał Massera, w przeciwieństwie do generała Videli, postrzegany był jako jeden z najbardziej radykalnych argentyńskich generałów, zwolennik zdecydowanej i bezwzględnej walki z komunizmem światowym oraz utrzymania niezależności Argentyny na arenie międzynarodowej. Wielokrotnie wykorzystywał on prawa człowieka jako instrument mający na celu oczyszczenie własnego nazwiska oraz zwiększenie wpływów argentyńskiej marynarki wojennej poprzez

59 Organization of American States, Resolution 315 (VII-0/77). Promotion of Human Rights. Resolution adopted at the fourth plenary session, held on June 22, 1977, s. 78, [online] http://scm.oas.org/pdfs/ agres/ag03791E01.PDF, 12 XI 2018.

60 Public Law 95-148, Bill Summary \& Status, The Library of Congress, [online] https://www.congress. gov/bill/95th-congress/house-bill/7797, 12 XI 2018; W.M. Schmidli, Institutionalizing Human Rights..., s. 368.

61 M. Novaro, V. Palermo, La dictadura militar..., s. 283.

62 A. Brysk, The Politics of Human Rights in Argentina..., s. 58. 
zdyskredytowanie prezydenta Videli oraz przeniesienie na wojska lądowe pełnej odpowiedzialności za wszelkie nadużycia w państwie ${ }^{63}$. Przykładowo, pod koniec 1977 roku admirał Massera wysłał dwóch przedstawicieli argentyńskiej marynarki do Stanów Zjednoczonych, gdzie spotkali się oni z urzędnikami blisko związanymi z prezydentem Carterem. Celem wizyty było przekonanie Amerykanów, że istniejący w USA obraz argentyńskiej marynarki wojennej jako najbardziej radykalnego skrzydła sił zbrojnych, w największym stopniu odpowiadającego za represje, jest jedynie wymysłem generała Videli. Zapewnili oni urzędników, że admirał Massera gotowy był opublikować listę przetrzymywanych i zaginionych więźniów politycznych, co uniemożliwione zostało ze względu na opór sił lądowych, z generałami Jorge Videlą i Roberto Violą na czele ${ }^{64}$.

Kwestią, która w sposób najbardziej dobitny pokazała istotę sporu w łonie argentyńskich środowisk wojskowych, była sprawa Jacobo Timermana, redaktora naczelnego gazety „La Opinión”, od 1977 roku bardzo krytycznej wobec rządzących wojskowych. W połowie 1977 roku podejrzewani o lewicowe sympatie dziennikarze gazety zaczęli znikać z dnia na dzień, nie powstrzymało to jednak wydawców gazety przed publikacją kolejnych nieprzychylnych władzom artykułów. 15 lipca 1977 roku aresztowany został sam Timerman. Dziennikarz przewieziony został do jednego z centrów wojskowych, gdzie poddawany był torturom. Przypadek Timermana odbił się wyjątkowo głośnym echem w Stanach Zjednoczonych, głównie za sprawą społeczności żydowskiej, która bardzo mocno nagłośniła aresztowanie. Oto bowiem w sposób całkowicie pozbawiony podstaw prawnych doszło do uwięzienia cieszącej się uznaniem osoby publicznej, walczącej o wolność środków masowego przekazu, dodatkowo należącej do mniejszości religijnej. Naciski ze strony społeczności międzynarodowej były ogromne, a amerykański Senat zagroził zerwaniem stosunków dyplomatycznych $\mathrm{z}$ Argentyną w razie odmowy przez wojskowych natychmiastowego wypuszczenia Timermana ${ }^{65}$. Presja wywierana na argentyńską juntę była tak wielka, że prezydent Videla zdecydował o postawieniu Timermana przed sądem, który oczyścił dziennikarza z wszelkich zarzutów. W 1979 roku opuścił on Argentynę i osiadł w Izraelu, gdzie zajął się spisywaniem swoich wspomnień z okresu aresztowania. Decyzja generała Videli o ugięciu się pod presją i wypuszczeniu Timermana spotkała się z ogromną krytyką wewnątrz sił zbrojnych. Najbardziej radykalni domagali się dymisji ministra sprawiedliwości Alberta Rodrígueza Vareli, podkreślając, że zgoda na wypuszczenie Timermana jeszcze bardziej pogorszyła wizerunek Argentyny w oczach społeczności międzynarodowej. Stało się bowiem jasne, że to rząd argentyński jest stroną łamiącą prawo i odpowiedzialną za wymuszone porwania niewygodnych politycznie jednostek. Opublikowana przez Timermana książka Więzień bez imienia, cela bez numeru, odsłaniająca kulisy działania argentyńskiego reżimu, dodatkowo osłabiła pozycję

63 M. Novaro, V. Palermo, La dictadura militar..., s. 284.

64 C. Uriarte, Almirante Cero. Biografía no autorizada de Emilio Eduardo Massera, Buenos Aires 1992, s. 190-191.

65 M. Novaro, V. Palermo, La dictadura militar..., s. 286. 
umiarkowanych w środowisku argentyńskich wojskowych. Potwierdziły się bowiem słowa radykałów, od początku stojących na stanowisku, że w interesie argentyńskiego rządu wojskowego nie leży, aby jakakolwiek jednostka przetrzymywana w tajnym więzieniu wyszła z niego żywa, szczególnie jeśli jest to osoba znana ${ }^{66}$.

Sprawa Timermana i inne głośne przypadki potwierdzające niskie standardy przestrzegania praw człowieka w Argentynie doprowadzały do zwiększenia nacisków na rząd wojskowy w celu wymuszenia zgody na wizytę przedstawicieli CIDH w państwie. Propozycja pierwotnie złożona w 1977 roku spotkała się z ponowną odmową na początku roku 1978. Warto podkreślić, że niechęć Argentyny do poddania się kontroli wynikała nie tylko z faktu, że postrzegano ją jako interwencję w sprawy wewnętrzne państwa, ale również ze względu na silne w Argentynie przekonanie, że OPA, a szczególnie Międzyamerykańska Komisja Praw Człowieka, służy w pierwszej kolejności realizacji celów politycznych Stanów Zjednoczonych. Wrażenie to potęgowal fakt, że na czele CIDH stał ówcześnie Amerykanin, Tom Farer ${ }^{67}$.

Zmiana stanowiska Argentyny w stosunku do wizyty CIDH nastąiła jednak niespodziewanie szybko. Związana była z kolejnymi sankcjami ekonomicznymi nałożonymi przez Stany Zjednoczone na rząd wojskowy. W połowie 1978 roku Bank Eksportowo-Importowy Stanów Zjednoczonych zablokował dwie pożyczki dla Argentyny opiewające na kwotę $550 \mathrm{mln}$ dolarów. Odmowa przyznania środków finansowych, w swoim założeniu mających być przeznaczonymi na dalszą budowę zapory wodnej Yaciretá na rzece Parana, bardzo mocno utrudniłaby argentyńskie plany kontynuowania rozpoczętej w 1974 roku inwestycji. We wrześniu 1978 roku w Rzymie, przy okazji pogrzebu papieża Jana Pawła I, doszło do spotkania prezydenta Videli i wiceprezydenta Stanów Zjednoczonych Waltera Mondale’a. Argentyński wojskowy wykorzystał spotkanie do przekonania amerykańskiego polityka do zmiany decyzji jego rządu w sprawie udzielanych Argentynie kredytów. Mondale, z upoważnienia prezydenta Cartera, poinformował Videlę, że decyzja o nieprzyznaniu Argentynie pomocy finansowej może być zmieniona tylko i wyłącznie, jeśli Buenos Aires zgodzi się na wizytację przedstawicieli CIDH w roku $1979^{68}$. Mimo oporu ze strony radykalnej części armii, niejako przyparty do muru argentyński rząd zgodził się na przyjęcie delegacji $\mathrm{CIDH}$ mającej sporządzić raport o stanie przestrzegania praw człowieka w Argentynie. Wojskowi zdecydowali się na wystosowanie oficjalnego zaproszenia, którego celem miało być pokazanie światu, że planowana kontrola przeprowadzona będzie z inicjatywy wyłącznie rządu argentyńskiego, który nie ma nic do ukrycia ${ }^{69}$. Mimo to, w czasie ustalania z przedstawicielami OPA warunków wizyty komisji, argentyńskie Ministerstwo Spraw Zagranicznych próbowało przeforsować propozycję ograniczenia wizytacji jedynie do rozmów z argentyńskimi urzędnikami. Została ona odrzucona przez komisję,

\footnotetext{
Tamże.

67 D.M.K. Sheinin, Argentina and the United States. An Alliance Contained, Athens, GA 2006, s. 168.

68 M. Novaro, V. Palermo, La dictadura militar..., s. 290.

69 D.C. D’Antonio, Derechos humanos y estrategias de la oposición bajo la dictadura militar argentina, „Tensões Mundiais” 2010, vol. 6, nr 11, s. 156.
} 
która ostatecznie zapewniła sobie prawo do swobody wyboru środków przeprowadzenia misji, z wyjątkiem zakazu wstępu do argentyńskich baz militarnych ${ }^{70}$.

Wizyta przedstawicieli CIDH w Argentynie rozpoczęła się 6 września 1979 roku i trwała dwa tygodnie. Siedmioosobowa delegacja, na czele z Wenezuelczykiem Andrésem Aguilarem, w czasie pobytu w Argentynie odwiedziła więzienia, centra wojskowe (w tym Szkołę Mechaników Marynarki Wojennej), cmentarze, urzędy, zarówno w Buenos Aires, jak i w innych argentyńskich miastach. Przeprowadzono wywiady z wysokimi urzędnikami państwowymi, przedstawicielami zdelegalizowanych partii politycznych (m.in. przyszłym prezydentem demokratycznej Argentyny Raúlem Alfonsínem) oraz związków zawodowych, a także osadzonymi więźniami i zwykłymi ludźmi, najczęściej rodzinami zaginionych lub uwięzionych ${ }^{71}$. Członkowie komisji wielokrotnie rozmawiali również z przedstawicielami argentyńskich organizacji i grup pozarządowych. W celu przedstawienia komisji opracowanych przez siebie raportów, wielu z nich przyjeżdżało do Buenos Aires z Mendozy, Rosario, La Platy i innych odleglejszych miast ${ }^{72}$. Zarówno w Buenos Aires, jak i w Córdobie oraz San Miguel de Tucumán CIDH zatożyta swoje biura, w których każdy zainteresowany mógt ztożyć doniesienie $w$ sprawie naruszeń praw cztowieka, jakich doświadczyt w państwie. Tysiace osób ustawiato sie $w$ gigantycznych kolejkach, aby porozmawiać z komisja oraz przedstawić swoja historię. Przez dwa tygodnie wizytacji ztożonych zostato 5580 doniesień w sprawie wymuszonych zaginięć - liczba ta przerosta zarówno szacunki rzadu wojskowego, jak i wszelkie oczekiwania cztonków komisji, którzy nie spodziewali się aż tak wielkiego zainteresowania ze strony Argentyńczyków ${ }^{73}$.

Raport CIDH dotyczący Argentyny ukończony został 14 grudnia 1979 roku, jednak do jego oficjalnej prezentacji doszło w kwietniu 1980 roku. Na 374 stronach przedstawiono dogłębną analizę standardów życia politycznego i społecznego, wskazując liczne nadużycia, do których dochodziło w Argentynie między rokiem 1975 a $1979^{74}$. Według komisji Argentyna zatraciła wszelkie cechy typowe dla demokratycznego państwa prawa, o czym świadczyć miały poważne naruszenia podstawowych swobód, takich jak: prawo do życia, integralności jednostki, sprawiedliwości, wolności oraz uczciwego procesu. Osobny rozdział dokumentu poświęcony został wymuszonym zaginięciom. Dokonano w nim dokładnej analizy owego procederu, jak również opisano szereg przypadków osób poddanych tego typu represjom. Należy jednak zwrócić uwagę, że fakt całkowitego nieprzestrzegania standardów praw człowieka w Argentynie był jednym z wniosków płynących z lektury raportu. Drugim z nich, równie istotnym, było bezapelacyjne i całkowite wskazanie aparatu władzy państwowej jako winnego owych naruszeń. W ostatniej, podsumowującej części raportu przeczytać można, że: w okresie

\footnotetext{
70 M. Novaro, V. Palermo, La dictadura militar..., s. 294-296.

71 M.L. San Martino de Dromi, Historia politica Argentina (1955-1988), Buenos Aires 1988, s. 277.

72 D.C. D’Antonio, Derechos humanos y estrategias..., s. 169.

73 M. Novaro, V. Palermo, La dictadura militar..., s. 296.

74 Informe sobre la situación de los derechos humanos en Argentina, 11 IV 1980, [online] http://www.cidh. org/countryrep/Argentina80eng/toc.htm, 12 XI 2018.
} 
objętym raportem, $z$ powodu dziatań lub zaniechania dziatania ze strony organów państwowych, doszto w Republice Argentyńskiej do wielu poważnych naruszeń praw cztowie$k a, w$ tym praw podstawowych, gwarantowanych przez Amerykańska Deklaracje Praw i Obowiazków Cztowieka. [...] osoby zwiazane z rzadowymi agencjami bezpieczeństwa zadaty śmierć wielu kobietom i mężczyznom, bezpośrednio po ich uwięzieniu w tajnych aresztach $^{75}$.

Stanowczy i jednoznacznie potępiający raport CIDH był dużym zaskoczeniem dla rządzących wojskowych. Zarówno bowiem prezydent Videla, jak i większość wojskowych liczyli, że komisja weźmie pod uwagę liberalizację reżimu po roku 1978, kiedy to znacząco zmniejszyła się liczba przetrzymywanych w tajnych więzieniach. Argentyńscy wojskowi od początku wyszli z mylnego założenia, zakładając, że podjęte przez nich działania zmierzające w kierunku zakończenia „brudnej wojny” stanowić będą dostateczny dowód na to, iż Argentyna jest państwem demokratycznym, w którym zachowane są wszelkie standardy przestrzegania praw człowieka. $Z$ punktu widzenia komisji jednak, skala nadużyć, do jakich dochodziło w Argentynie na przestrzeni lat, całkowicie przysłaniała tak mocno podkreślane przez generałów zmiany dokonujące się w ciągu kilku ostatnich miesięcy ${ }^{76}$. Należy też zwrócić uwagę, że nadzieja argentyńskich generałów na pozytywny wynik wizytacji wynikała w znacznym stopniu również z faktu, że przez cały okres prezydentury Cartera nie poczuwali się oni do zarzucanych im czynów. W obliczu kontroli CIDH wojskowi w dalszym ciągu traktowali swoje działania jako usprawiedliwione udziałem w wojnie ze światowym komunizmem oraz koniecznością obrony państwa i narodu przed grupami i jednostkami, które winne były zniszczenia integralności i spójności społecznej. Argentyna spowiada się tylko przed Bogiem - mówił w czasie wizyty komisji argentyński minister spraw wewnętrznych, generał Albano Harguindeguy ${ }^{77}$. Bezpośrednio po upublicznieniu raportu argentyński rząd wojskowy wystosował oficjalną deklarację, w której oskarżał komisję o nierzetelność oraz sporządzenie dokumentu w złej wierze. Zwrócono w nim uwagę, że jego twórcy całkowicie zignorowali kontekst, w jakim doszło do objęcia władzy przez juntę, bez którego znajomości niemożliwa jest obiektywna ocena ówczesnej sytuacji panującej w państwie ${ }^{78}$.

Raport na temat Argentyny odbił się szerokim echem również w kręgach administracji prezydenta Cartera. Konkluzje dokumentu nie pozostawiały złudzeń, że argentyński rząd wojskowy odpowiedzialny jest za naruszenia praw człowieka na szeroką skalę, za co należy mu się jednoznaczne potępienie. Okazją do poruszenia owej kwestii okazało się 10. posiedzenie Zgromadzenia Ogólnego OPA w listopadzie 1980 roku. W jego trakcie delegacja Stanów Zjednoczonych zaprezentowała projekt rezolucji końcowej potępiającej naruszenia praw człowieka, w której wymienione były państwa ocenione przez $\mathrm{CIDH}$ jako nieprzestrzegające międzynarodowych standardów w tym

Tamże, tłum. własne.

76 M. Novaro, V. Palermo, La dictadura militar..., s. 298.

77 M.L. San Martino de Dromi, Historia politica..., s. 271.

78 A. Cisneros, C. Escudé, Las relaciones con Estados Unidos... 
zakresie. Amerykanie podkreślali, że kolejna rezygnacja z enumeratywnego potępienia winnych całkowicie osłabiłaby zarówno ciężar sankcji, jaką niesie za sobą rezolucja, jak i autorytet samej komisji sporządzającej raporty, będącej organem odpowiedzialnym za kontrolę państw pod kątem przestrzegania praw człowieka ${ }^{79}$. Przedstawiciele Argentyny potraktowali ową propozycję jako absolutnie nie do przyjęcia, dyskryminującą w stosunku do władz w Buenos Aires. Podkreślali oni, że prawdziwym zagrożeniem dla jedności kontynentów amerykańskich jest ofensywa sowiecko-kubańska, przeciwko której administracja Cartera, w przeciwieństwie do rządu argentyńskiego, nie podjęła żadnych działań. Spór z delegacją amerykańską oraz lektura raportu CIDH na forum Zgromadzenia nieomal doprowadziły do zerwania obrad, Argentyna zagroziła bowiem wystąpieniem z OPA. Ostatecznie jednak, dzięki mediacji ze strony większości państw latynoamerykańskich, przyjęto rezolucję końcową, będącą kompromisem w stosunku do skrajnych pozycji Waszyngtonu i Buenos Aires. Wbrew naciskom Amerykanów, dokument nie potępiał Argentyny, a jedynie wymieniał ją w gronie państw o niskich standardach przestrzegania praw człowieka ${ }^{80}$.

Spór na forum OPA w listopadzie 1980 roku okazał się ostatnią konfrontacją administracji Cartera z argentyńskim rządem wojskowym. W grudniowych wyborach prezydenckich bowiem amerykański prezydent, którego poparcie wewnątrz państwa systematycznie spadało, nie zdołał uzyskać reelekcji. W sprawowanej funkcji zastąić miał Cartera Ronald Reagan. Już sama kampania wyborcza kandydata republikanów opierała się na całkowitej krytyce założeń politycznych prezydenta Cartera, podkreślając szkodliwość i nieefektywność realizowanej przez niego doktryny. Oczywiste stało się więc, że linia polityczna przyjęta przez nowego prezydenta będzie odmienna także w stosunku do potępianej przez Cartera Argentyny. Nowa linia polityczna amerykańskiej administracji pasowała do argentyńskiej doktryny bezpieczeństwa narodowego, zakładającej walkę z siłami lewicowymi nie tylko wewnątrz państwa, ale również poza jego granicami. Znalazło to swoje potwierdzenie we współpracy dwóch państw w Ameryce Środkowej w zakresie współtworzenia oddziałów contras działających na rzecz obalenia rewolucyjnego rządu sandinistów w Nikaragui ${ }^{81}$.

Pozytywny stosunek USA do Argentyny w tym okresie przejawiał się również w działaniach amerykańskiego prezydenta mających na celu zniesienie ograniczeń i barier pomocy finansowej wprowadzonych przez administrację Cartera. Odcięcie się Reagana od doktryny przyjętej przez jego poprzednika doprowadziło do przekonania Argentyńczyków o wielkiej wadze sojuszu Buenos Aires z Waszyngtonem. Prawa człowieka przestały być istotnym wyznacznikiem polityki USA w stosunku do Argentyny, podobnie jak innych państw trzecich. Idealistyczny projekt oparcia polityki zagranicznej na wartościach poddany został całkowitej krytyce, ustępując miejsca doktrynie walki z komunizmem.

\footnotetext{
79 Tamże.

80 Tamże.

81 Więcej na ten temat: A. Armony, Argentina, the United States...
} 


\section{PODSUMOWANIE}

Należy zwrócić uwagę, że rządzona przez wojskowych Argentyna należała do grupy państw, w stosunku do których amerykańska polityka praw człowieka realizowana była w sposób najbardziej energiczny. Przykład relacji USA z Argentyną w czasie prezydentury Jimmy'ego Cartera jest szczególnie ważny, pozwala on bowiem na wyciągnięcie szerokich wniosków dotyczących funkcjonowania przyjętej przez prezydenta doktryny praw człowieka.

Panuje powszechna zgoda co do faktu, że linia polityczna demokratycznego prezydenta oparta była na szlachetnych założeniach, wprowadzając nową jakość do amerykańskiej polityki zagranicznej. Trudno również zaprzeczyć, że działania podejmowane przez argentyński rząd godziły w podstawowe prawa człowieka i godne były potępienia. Administracja Cartera jako pierwsza zdecydowała się przeciwstawić wojskowej juncie, opowiadając się po stronie tysięcy osób, które w czasie dyktatury stały się ofiarami terroru państwowego. $Z$ ideologicznego punktu widzenia doktryna Cartera jawi się więc jako jednoznacznie pozytywny, szlachetny projekt polityczny. Z drugiej jednak strony, dokonując oceny Carterowskiej polityki praw człowieka, konieczne jest odniesienie się do wymiaru praktycznego, a więc jej skuteczności. Przykład Argentyny doskonale pokazuje, że z politycznego punktu widzenia nie można mówić o pełnym sukcesie polityki praw człowieka, a hipotezę postawioną we wstępie do niniejszego artykułu uznać można za zweryfikowaną.

Nie ulega wątpliwości, że nałożone przez Stany Zjednoczone sankcje połączone z naciskami politycznymi na forum organizacji międzynarodowych przyczyniły się do częściowej liberalizacji reżimu po roku 1978. Niewątpliwym sukcesem amerykańskiej dyplomacji było wymuszenie na Argentynie zgody na kontrolę Międzyamerykańskiej Komisji Praw Człowieka, której raport ukazał światu prawdziwe oblicze argentyńskiej dyktatury. Zasługą Amerykanów była też aktywizacja argentyńskich organizacji pozarządowych, takich jak Matki z Placu Majowego czy Stałe Zgromadzenie Praw Człowieka (Asamblea Permanente por los Derechos Humanos, APDH). Z drugiej jednak strony, co podkreślone zostało w artykule, Stanom Zjednoczonym nie udało się całkowicie wpłynąć na postawę argentyńskich wojskowych, przekonanych o słuszności swoich działań nawet w obliczu sankcji. Co więcej, restrykcyjna polityka Amerykanów w stosunku do Argentyny doprowadziła do umocnienia się wśród wojskowych przedstawicieli środowisk radykalnych, czego głównym dowodem było objęcie funkcji prezydenckiej przez generała Leopolda Galtieriego w 1981 roku.

Problemem prezydenta Cartera, widocznym również w przypadku relacji z Argentyną, był brak szerokiego poparcia dla jego polityki wewnątrz kraju. Poza opozycją republikańską, niejako naturalnie opowiadającą się przeciwko linii politycznej obranej przez demokratów, prezydentowi nie udało się zyskać przychylności konserwatywnych środowisk wojskowych oraz służb specjalnych, w dalszym ciągu opowiadających się za koniecznością walki ze światowym komunizmem. Na znak protestu dla prowadzonej przez Cartera polityki, agenci CIA nagminnie odmawiali raportowania w kwestiach 
przestrzegania praw człowieka, nie wahając się jednocześnie przed współpracą z argentyńskim wywiadem w Ameryce Środkowej. Doktryna Cartera nie znalazła przychylności również w amerykańskim środowisku biznesowym, utrzymującym bliskie kontakty handlowe z Argentyną. Prezydent Carter nie zrobił nic w celu zatrzymania ogromnych przepływów finansowych płynących do Argentyny z rąk prywatnych przedsiębiorców, co w niewątpliwy sposób wpłynęło na zmniejszenie skuteczności nakładanych przez USA sankcji. Wyjątkowo głośnym przypadkiem było otwarte poparcie dla Argentyny udzielone przez amerykańskiego miliardera Davida Rockefellera, który publicznie skrytykował restrykcje nakładane na Buenos Aires przez rząd amerykański, twierdząc, że ustrójpanujacy w Argentynie sprzyja prywatnym przedsiębiorcom ${ }^{82}$. Warto wspomnieć, że w okresie prezydentury Cartera argentyńsko-amerykańska wymiana handlowa znacząco zwiększyła się, mimo nakładanych przez USA sankcji. W 1979 roku amerykański eksport do Argentyny wzrósł o prawie 140\% w stosunku do roku poprzedniego, osiągając wartość $1,7 \mathrm{mln}$ dolarów ${ }^{83}$.

Brak szerokiego poparcia dla polityki praw człowieka nie pozwolił prezydentowi Carterowi na pełną realizację zakładanych celów politycznych. Głównie z tego powodu głoszona przez niego doktryna pozostała w znacznej mierze idealistycznym projektem, oddalonym od panujących w kraju i poza jego granicami realiów. Ambicją Cartera było prowadzenie twardej linii politycznej w stosunku do Argentyny jako państwa nagminnie łamiącego prawa człowieka. Nakładane przez USA sankcje ekonomiczne i militarne okazały się dla dyktatorów uciążliwe, nie doprowadziły jednak do sparaliżowania argentyńskiej gospodarki i sfery obronności. Innymi słowy, nie wymusiły na argentyńskich dyktatorach przeprowadzenia zmian systemowych, które zadowoliłyby administrację Cartera. W tych okolicznościach nie można mówić o sukcesie amerykańskiej polityki praw człowieka w stosunku do Argentyny.

\section{BIBLIOGRAFIA}

93rd Congress, 1st session, Human Rights in the World Community: A Call for U.S. Leadership, a Report of the Subcommittee on International Organizations and Movements of the Committee on Foreign Affairs, U.S. Congress, House of Representatives, Washington 1974.

Apodaca C., U.S. Human Rights Policy and Foreign Assistance. A Short History, „Ritsumeikan International Affairs" 2005, vol. 3.

Argentina since Independence, red. L. Bethell, Cambridge 1993.

Armony A.C., Argentina, the United States, and the Anti-Communist Crusade in Central America, 1977-1984, Athens, OH 1997.

Arriagada Herrera G., El pensamiento politico de los militares (estudios sobre Chile, Argentina, Brasil y Uruguay), Buenos Aires 1986.

82 M.L. Weisz, The Will for Human Rights. U.S. Policy toward Argentina, 1976-1980, „Iberoamerica Global" 2008, vol. 1, nr 1, s. 89.

83 R. Cohen, Human Rights Diplomacy..., s. 238-239. 
Assistant Secretaries of State for Democracy, Human Rights, and Labor, [online] https://history. state.gov/departmenthistory/people/principalofficers/assistant-secretary-for-democracyhuman-rights-labor-affairs.

Bayer O., Borón A.A., Gambina J.C., El Terrorismo de Estado en la Argentina. Apuntes sobre su historia y sus consecuencias, Buenos Aires 2010.

Bloomfield L.P., From Ideology to Program to Policy. Tracking the Carter Human Rights Policy, „Journal of Policy Analysis and Management” 1982, vol. 2, nr 1, https://www.doi. org/10.2307/3323646.

Bravo N., El discurso de la dictadura militar argentina (1976-1983). Definición del opositor político y confinamiento - „valorización” del papel de la mujer en el espacio privado, „Utopía y Praxis Latinoamericana” 2003, nr 22.

Brysk A., The Politics of Human Rights in Argentina. Protest, Change, and Democratization, Stanford 1994.

Carter J., Keeping Faith. Memoirs of a President, Toronto 1982.

Cisneros A., Escudé C., Las relaciones con Estados Unidos, [w:] Historia general de las relaciones exteriores de la República Argentina, t. 14: Las relaciones politicas, 1966-1989, [online] http://www.argentina-rree.com/14/14-043.htm.

Cohen R., Human Rights Diplomacy: The Carter Administration and the Southern Cone, „Human Rights Quarterly” 1982, vol. 4, nr 2, http://dx.doi.org/10.2307/762130.

Cohen S.B., Conditioning U.S. Security Assistance on Human Rights Practices, „American Journal of International Law” 1982, vol. 76, nr 2, https://doi.org/10.2307/2201453.

Cohen S.B., Integrating Human Rights in US Foreign Policy. The History, the Challenges, and the Criteria for an Effective Policy, 2008, [online] https://www.brookings.edu/wp-content/ uploads/2016/06/04_human_rights_cohen.pdf.

Corigliano F.M., Colapso estatal y politica exterior. El caso de la Argentina (des)gobernada por Isabel Perón (1974-1976), „Revista SAAP” 2007, vol. 3, nr 1.

D’Antonio D.C., Derechos humanos y estrategias de la oposición bajo la dictadura militar argentina, „Tensões Mundiais” 2010, vol. 6, nr 11.

Derian Call on President Videla, 11 VIII 1977, [online] https://aad.archives.gov/aad/ createpdf ? $\mathrm{rid}=181457 \& \mathrm{dt}=2532 \& \mathrm{dl}=1629$.

Flood P.J., The Effectiveness of U.N. Human Rights Institutions, Westport, CT 1998.

Genovese M., Morgan I., Remembering Watergate, [w:] Watergate Remembered. The Legacy for American Politics, red. M. Genovese, J. Morgan, New York 2012.

Graham-Yooll A., Buenos Aires, otoño 1982. La guerra de Malvinas según las crónicas de un corresponsal inglés, Buenos Aires 2007.

Hartmann H., US Human Rights Policy under Carter and Reagan, 1977-1981, „Human Rights Quarterly” 2001, vol. 23, nr 2, https://doi.org/10.1353/hrq.2001.0017.

Hollingshead-Cook K., Ideology vs. Practice in Argentina's Dirty War Repression, University of Tennessee Honors Thesis Projects, [online] http://trace.tennessee.edu/cgi/viewcontent. cgi ?article $=1969 \&$ context $=$ utk_chanhonoproj.

Informe sobre la situación de los derechos humanos en Argentina, 11 IV 1980, [online] http:// www.cidh.org/countryrep/Argentina80eng/toc.htm. 
Jimmy Carter: Address at Commencement Exercises at the University of Notre Dame, 22 V 1977 , [online] http://www.presidency.ucsb.edu/ws/index.php?pid=7552.

Jimmy Carter: Inaugural Address, 20 I 1977, [online] https://www.presidency.ucsb.edu/docu ments/inaugural-address-0.

John F. Kennedy: Inaugural Address, 20 I 1961, [online] https://www.presidency.ucsb.edu/ documents/inaugural-address-2.

Kane J., American Values or Human Rights? U.S. Foreign Policy and the Fractured Myth of Virtuous Power, „Presidential Studies Quarterly” 2003, vol. 33, nr 4, [online] https://doi. org/10.1046/j.0360-4918.2003.00084.x.

Kaufman V.S., The Bureau of Human Rights during the Carter Administration, „The Historian” 1988, vol. 61, nr 1, https://doi.org/10.1111/j.1540-6563.1998.tb01423.x.

Lunch W., Sperlich P.W., American Public Opinion and the War in Vietnam, „The Western Political Quarterly” 1979, vol. 32, nr 1, https://doi.org/10.2307/447561.

McCrisken T.B., American Exceptionalism and the Legacy of Vietnam. US Foreign Policy since 1974, New York 2003.

Meeting with President Jorge Rafael Videla of Argentina Remarks to Reporters Following the Meeting, 9 IX 1977, [w:] Weekly Compilation of Presidential Documents, Monday, July 4, 1977, vol. 13, nr 27.

Novaro M., Palermo V., La dictadura militar, 1976/1983. Del golpe de estado a la restauración democrática, Buenos Aires 2011, Historia Argentina, 9.

Nunca más. Informe de la Comisión Nacional sobre la Desaparición de Personas, Buenos Aires 2010. Organization of American States, Resolution 315 (VII-0/77). Promotion of Human Rights. Resolution adopted at the fourth plenary session, held on June 22, 1977, [online] http://scm.oas. org/pdfs/agres/ag03791E01.PDF.

Presidential Directive/NSC-30, 17 II 1978, [online] https://fas.org/irp/offdocs/pd/pd30.pdf.

Presidential Review Memorandum/NSC-28: Human Rights, 8 VII 1977, [online] https://fas. org/irp/offdocs/prm/prm28.pdf.

Proclama, 24 de marzo de 1976, [w:] Documentos básicos y bases politicas de las Fuerzas Armadas para El Proceso de Reorganización Nacional, Buenos Aires 1980.

Public Law 87-195, Foreign Assistance Act of 1961, Approved September 4, 1961, [online] https:// legcounsel.house.gov/Comps/Foreign\%20Assistance\%20Act\%20Of\%201961.pdf.

Public Law 94-329 (The Arms Export Control Act), 30 VI 1974, [online] http://www.gpo.gov/ fdsys/pkg/STATUTE-90/pdf/STATUTE-90-Pg729.pdf.

Public Law 95-148, Bill Summary \& Status, The Library of Congress, [online] https://www. congress.gov/bill/95th-congress/house-bill/7797

Robben A.C.G.M., Political Violence and Trauma in Argentina, Philadelphia 2005.

Romero L.A., Breve historia contemporánea de la Argentina, Buenos Aires 2001.

San Martino de Dromi L., Historia politica Argentina (1955-1988), Buenos Aires 1988.

Schmidli W.M., Institutionalizing Human Rights in U.S. Foreign Policy. U.S.-Argentine Relations, 1976-1980, „Diplomatic History” 2001, vol. 35, nr 2, https://doi.org/10.1111/ j.1467-7709.2010.00951.x.

Schmidli W.M., The Fate of Freedom Elsewhere. Human Rights and U.S. Cold War Policy toward Argentina, Ithaca 2013. 
Schmitz D., The United States and Right-Wing Dictatorships, 1965-1989, Cambridge 2006.

Schmitz D., Walker V., Jimmy Carter and Foreign Policy of Human Rights. The Development of a Post-Cold War Foreign Policy, „Diplomatic History” 2004, vol. 28, nr 1, https://doi. org/10.1111/j.1467-7709.2004.00400.x.

Sheinin D.M.K., Argentina and the United States. An Alliance Contained, Athens, GA 2006.

Verbitsky H., Confessions of an Argentine Dirty Warrior, New York 2005.

Weisz M.L., The Will for Human Rights. U.S. Policy toward Argentina, 1976-1980, „Iberoamerica Global" 2008, vol. 1, nr 1.

United Nations, Resolution 33/173, Disappeared persons, 20 XII 1978, [online] https://undocs. org/pdf ?symbol=en/A/RES/33/173.

Uriarte C., Almirante Cero. Biografía no autorizada de Emilio Eduardo Massera, Buenos Aires 1992.

Magdalena LISIŃSKA - doktor nauk społecznych w zakresie nauk o polityce, pracuje w Zakładzie Ameryki Łacińskiej Instytutu Amerykanistyki i Studiów Polonijnych Uniwersytetu Jagiellońskiego. W 2018 roku obroniła rozprawę doktorską Ideologizacja polityki zagranicznej Argentyny w ramach Procesu Reorganizacji Narodowej 1976-1983. Przedmiotem jej naukowych zainteresowań jest polityka i historia państw latynoamerykańskich ze szczególnym uwzględnieniem Argentyny, wyzwania bezpieczeństwa w regionie Ameryki Łacińskiej i Karaibów oraz stosunki USA z Ameryką Łacińską. 